\title{
Metatextuality of Transnational Marriages in Updike's Terrorist
}

\author{
Riyad Abdurahman Manqoush ${ }^{1}$, Ruzy Suliza Hashim², Noraini Md. Yusof ${ }^{2}$ \\ ${ }^{1}$ Department of English, Faculty of Education, Hadhramout University, Yemen \\ ${ }^{2}$ School of Language Studies and Linguistics, National University of Malaysia \\ Email address: \\ riadmanqoush@yahoo.com (R. A. Manqoush), ruzy@ukm.my (R. S. Hashim), animy@ukm.my (N. Md. Yusof)
}

\section{To cite this article:}

Riyad Abdurahman Manqoush, Ruzy Suliza Hashim, Noraini Md. Yusof. Metatextuality of Transnational Marriages in Updike's Terrorist. International Journal of Literature and Arts. Vol. 2, No. 1, 2014, pp. 10-15. doi: 10.11648/j.ijla.20140201.13

\begin{abstract}
In this paper, we intend to analyse an American novel, John Updike's Terrorist (2006), with the aim of examining its critical standpoint of the American women' marriages to Muslim migrants. This essay explores the reasons which lead Updike to refuse this social hybridity and how that refusal disseminates biased attitude against the Muslim Americans in general. Having appropriated Gerard Genette's theory of metatextuality to frame our analysis of the novel, we argue that metatextuality refers to the texts' explicit or implicit critical treatment of one another. Our analysis of Updike's metatextuality of the transnational marriages concludes that Updike is extremely biased against the Arabs and Muslims because his refusal of these marriages concentrated merely on American women who marry Arab and Muslim migrants. He develops dialogues to expose the Arab Americans as having a strong Islamic identity which, as he claims, provokes them to reject the US liberal life and oppose the US policy and history. In addition to that, the novel reveals that American transnational matrimonies to Arabs result in confused American identities that live in-between spaces; they are neither Americans nor Arabs and their loyalties lie with the religion and culture of their Muslim fathers, not of the American mothers. This suspicion is intended to expose the Arab and Muslim Americans as dangerous for the US security. It also uncovers the author's ideology which stands against the Arabs and Muslims.
\end{abstract}

Keywords: Metatextuality, Transnational Marriage, Arab/Muslim Americans, John Updike

\section{Introduction}

In this paper, we intend to analyse an American novel, John Updike's Terrorist (2006), with the aim of examining its critical standpoint of the American women' marriages to Muslim migrants. While the main emphasis of the essay will be on the viewpoint of the author and narrator, the characters' voices will also be explored. This is because their opinions might consciously be employed by the author to support his criticism of the issue indicated above. Having appropriated Gerard Genette's theory of metatextuality to frame our analysis of the novel, we argue that metatextuality refers to the texts' explicit or implicit critical treatment of one another. In this essay, Updike's story will be considered as a metatext of what the author sees as an American social problem i.e. marriage to Arab and Muslim migrants. By the end of this essay, we hope to understand the reasons which lead Updike to refuse this social hybridity and how that refusal disseminates biased attitude against the Arab and Muslim Americans in general.

\section{Literature Review}

Due to the success and fame of Updike's literary works, they have been examined by many researchers. Among these researchers are Matthew Ashipe (2007: 228) who argue that "Updike has become increasingly aware of how in writing (and re-writing) his own personal history, he [has] also been recording America's during the second half of the twentieth century." This argument has apparently been elaborated by Ashipe in the excerpt below with a special emphasis on one of Updike's short fiction:

In stories such as My Father on the Verge of Disgrace (1997), Updike has made the financial uncertainty that plagued his family during childhood correlative with nation's experience during the Depression; similarity, he has cast his wartime patriotism, his dismay at the violence of the late sixties, and the slow demise of his first marriage (his separation from his first wife neatly corresponding with Nixon's resignation from the White House) as representative 
of his generation's experience (Ashipe 2007: 228, italics mine).

This quotation indeed refers to what Ashipe has illustrated previously that Updike's writings are similar to "his own personal history" (Ashipe 2007: 228). He was a writer who was socially aware of his surroundings, and his works reflected his personal interest in the events of the time. Ashipe (2007: 228-9) ends his study with the statement that Updike's "fiction offers an exhaustive an intimate chronicle of a life lived in post war America, one that richly records, and immortalizes, the experience of being alive during the second half of the twentieth century." This indicates that Updike mirrored the circumstances of his society in literary productions

In addition to that, Cynthia Deitering (2008: 13) "attempt[s] a sort of geneology of U.S. fiction since 1980 in order to make the inchoate postnatural experience and implications of this period accessible and trenchant to us now." Therefore, she examines the works "of Don DeLillo, John Updike, Paule Marshall, John Gardner, William Gaddis, Margaret Atwood, Meridel Le Sueur, John Cheever, Saul Bellow" (Deitering 2008: v). Due to the scope of this paper, we will merely refer to the part that deals with John Updike. In her analysis of "an example of embodied fiction," Deitering (2008: 14) claims that "the interior narratives of the characters' damaged bodies continually interrupt the text of John Updike's Rabbit at Rest." Since this argument seems to be ambiguous, Deitering (2008: 14) elucidates it in the excerpt below:

Updike's narrative in Rabbit at Rest juxtaposes old and new notions of home by using the dual settings of a native home in Pennsylvania, shaped by the cycles of nature and experiences of the dwellers, and a Florida retirement condo, a home in which nature is eclipsed and which is shaped not by the experiences and rhythms of the dweller but by the dictates and technologies of real estate and land speculation.

Concluding her research, Deitering (2008: v) alleges that "fiction of this period [i.e. 1980s] is important in that it illuminates what might otherwise be a forgotten part of our cultural history." Besides, she claims that the writings of the authors including Updike "reflect the radical ontological shift that we experienced during the 1980s and have perhaps already begun to forget in the cultural landscape of the $21 \mathrm{st}$ century" (Deitering 2008: v). The marriages of American women to Arab Muslim migrants is one of the main issues, which were overt in Updike's works as will be shown when analysing his latest novel Terrorist further.

By the same token, Riyad Manqoush et al. (2011: 57) explore Updike's Terrorist (2006) "with the aim of examining the use of allusion in the depiction of 9/11 acts and the US occupation of Iraq". Their paper concludes that "Updike alludes to history to affirm that Arab terrorists are the main enemies of the USA and also to oppose the actions of those terrorists who give themselves the right to kill civilians" (Manqoush et al. 2011: 57). Besides, "it also employs irony to oppose the US intervention in the Middle East" (Manqoush et al. 2011: 66). In this essay, we will examine the same novel but our focus will not be on history. It will centre on Updike's critical treatment of the marriages of American women to Arab and Muslim, which he considers as a social crisis as will be analysed further.

\section{Metatextuality}

We have illustrated earlier that we will appropriate the theory of metatextuality to frame our analysis of Updike's Terrorist. Before defining this theory, we should indicate that there is a link between word "metatextuality" and other concepts such as metafiction, metahistory, metalanguage, metaanalysis, and also metacriticism. This is because they all share the use of the prefix "meta". This prefix is Greek in origin and means "beyond", "above", "over" and also "about" (Pape 2008: 3; Popham 2008: 18). To be clearer, we will analyse one of the concepts above, particularly metafiction, to expose what the prefix "meta" added to its meaning. This discussion can be of great assistance in understanding what is meant by metatextuality.

The term "metafiction", which was coined by William $\mathrm{H}$. Grass in 1970, means "fiction about fiction: or more especially a kind of fiction that openly comments on its own fictional status ... the term is normally used for works that involve a significant degree of self-consciousness about themselves as fictions" (Baldick 1990: 133). Thus, "metafiction" refers to a literary text that is written about another. It is called metafiction because it is consciously or unconsciously written "over" and "about" another fiction. As an example of metafiction, Robert Stam and Alessandra Raengo (2005: 29) in the quotation below expose a number of literary works that criticise, oppose or provide different perspectives of other narratives:

Jean Rhys's The Wide Sargasso Sea (1966) retells Charlotte's Jane Eyre as the story of Bertha Mason, $\mathrm{Mr}$ Rochester's first wife and the by-now-celebrated "madwoman in the attic" of feminist criticism, leading us to reassess the racialized presentation of Berth as a "creole savage." ... Another recent trend within literature involves the rewriting of a novel from the perspective of secondary or even imaginary additional characters. Thus we get Robinson Crusoe rewritten from the perspective of Susan Barton (Coetzee's Foe), Moby Dick from the perspective of the wife of Captain Ahab (Sena Naslund's Ahab's Wife), Lolita from the perspective of Lolita (Pia Pera's Lo's Diary), Don Quixote from the perspective of a female Quixote (Kathy Acker's Don Quixote). Here the possible permutations become endless, since any novel could be written from the perspective of a different character: an ecological rewriting of Moby Dick might give us Captain Ahab from the point of view of the whale (Italics and brackets original).

Although these works utilise different approaches, they all show critical responses to earlier literary writings. In 
metafiction, the new authors express their oppositional views and disagreements about some events or characters which were presented in earlier works, but they present their critiques in fictional and literary mould.

To link the previous discussions with our theoretical framework, "metafiction" is a critical use of fiction; "metahistory" is a critical use of history and the same with "metalanguage", "metaanalysis" and metacriticism". However, a problem appears in the terminology because the meaning of metafiction is only restricted to fiction. Similarly, metahistory is limited to history and also the same with metalanguage, metaanalysis and metacriticism. Thus, hundreds of terms might appear, using the prefix "meta", to reflect the same meaning. To overcome this duplication, Gerard Genette (1997: 4) has coined the term "metatextuality" to recapitulate any "commentary" and critical "relationship" between any two texts. He argues that the "metatextuality ... unites a given text to another, of which it speaks without necessarily citing it (without summoning it), in fact sometimes without naming it" (Genette 1997: 4, italics and brackets original). Since any meta's relation can briefly be identified as metatextuality, concepts such as metafiction, metahistory, metalanguage, metaanalysis and metacriticism will be removed because they are all under the umbrella of metatextuality.

Metatextuality sheds light on various "commentary" texts which are called "metatexts". According to Randal Holme (2004: 49), the "metatext is the use of text to comment upon itself, or to explain what it is saying." In other words, it is a text that criticises another. Relatively, Genette (1992: 82) illustrates that "all literary texts critics, for centuries, have been producing metatext without knowing it." This illustration coincides with Holme's argument that "students of academic writing may not be fully aware of how the way they cite a given authority may construct the view that they have of it. Such terms belong to what is called metatext" (Holme 2004: 49). This is because their writings normally reflect opinions about the texts they use. If it is not explicit critical analysis, it can be implicit criticism.

Based on the previous discussion, there are two types of metatextuality-explicit and implicit. In fact, we have derived this division from the discussions of a number of scholars. In addition to the ones illustrated earlier, Stam and Raengo (2005: 28) relate metatextuality to "the critical relation between one text and another, however the commented text is explicitly cited or silently evoked." The use of the words "explicitly" and "silently" is also repeated by Daniel Chandler (2007: 206) who argues that "metatextuality" refers to the "explicit or implicit critical commentary of one text on another text." In addition to that, Holme (2004: 49) indicates that the "metatext provides an implicit and explicit opportunity for the writer to give their own view on what they are saying." All these scholars indicate that there are two types of metatextuality. From the word "explicit", one can realise that this type of metatextuality indicates an obvious and direct commentary relation between two particular texts or more. In contrast, implicit metatextuality is always indirect because it is mostly achieved through the use of allusion. In this article, we will not separate these two types in our analysis of the novel because Updike stresses more on the explicit form. In case, he makes use of implicit metatextuality, it is merely employed to reinforce his explicit metatextuality. Therefore, separating the two types in this article is difficult.

\section{Metatextuality of Transnational Marriages in Updike's Terrorist}

The general theme of Updike's Terrorist stands against one of the contemporary social issues where American women get married to Arab and Muslim foreigners. Before we discuss some evidence that prove our argument, we will highlight a brief synopsis of the novel. Updike's Terrorist centres on an Arab-American young student called Ahmad who was born and brought up in the USA. At his third year, his Egyptian Muslim father decamps to his country, leaving Ahmad with his Christian American wife. Despite the absence of the father, Ahmad considers himself as a Muslim like his father, not as a Christian like his mother. His identity becomes more an Arab than an American. His enthusiasm towards Islam and Arab culture provokes an extremist imam to brainwash him to adopt a fanatic version of Islam. The story ends when the guidance counsellor of Ahmad's high school, Jack Levy, convinces Ahmad to stop working with that imam who exploits Ahmad to carry out terrorist actions against the US.

Consistent with the synopsis above, we need to elaborate on the same theme from the social angle. Sunaina Marr Maira (2009: 80) argues that many foreigners in the USA get married to American women because they realise that the US citizenship can be acquired quickly "through marriage" to American women. These marriages are almost like a business; the two couples are merely married on papers according to an agreement between a foreign husband and a local wife. However, these relationships often end in a tragic way when the couples have children. The husbands may leave the USA after they have completed their studies or work. Hence, children are left with their mothers, knowing nothing about their fathers except the name, origin, culture, and perhaps religion. This trauma is critically treated in Updike's novel as will be explained further.

Updike presents a number of portrayals that explicitly and implicitly condemn this kind of relationship. For instance, the depictions of Ahmad, who is a son of an American mother and Egyptian father, indicate that the boy does not belong to the USA. He is rejected by the Americans and conversely he discards the American culture. This feeling of alienation colonises Ahmad because his Egyptian father left him when he was at the age of three. This can be seen in the quotation below where Ahmad talks to the school guidance counsellor, Jack, who invites him to his office and asks him about his biography: 
I am the product of a white American mother and an Egyptian exchange student; they met while both studied at the New Prospect campus of the State University of New Jersey. My mother, who has since become a nurse's aide, at the time was seeking credits toward an art degree. She paints and designs jewellery in her spare time, with some success, though not enough to support us. ... He had hoped, my mother has explained to me, to absorbed lessons in American enterprise and marketing techniques. It was not as easy as he had been told it would be. His name was-is; I very much feel he is still alive-Omar Ashmawy, and hers is Teresa Mulloy. She is Irish-American. They Married well before I was born. I am legitimate... My father well knew that marrying an American citizen, however trashy and immoral she was, would gain him American citizenship, and so it did, but not American know-how, nor the network of acquaintance that leads to American prosperity. Having despaired of ever earning more than menial living by the time I was three, he decamped (p.32-3).

Being a "product of a white American mother and an Egyptian exchange student" makes him a hybrid who lives in constant psychological limbo. He was born as a Muslim before his father "decamped", but he now lives with his Christian mother in New Jersey. Therefore, his "American citizenship" becomes in conflict with his Islamic and Arabic identity. In the following discussions, we will elucidate a number of quotations which reinforce this conflict.

Ahmad's pride of being a Muslim hurts the feeling of his Christian mother. For instance, Jack's wife, Elizabeth tells her sister, Hermione, that Ahmad 'thinks he's a Muslim because his deadbeat father was, at the same time ignoring this hardworking Irish-Catholic mother he lives with. Think of what our parents would have said if we'd brought Muslim men to marry" (p.129). Even though his American "mother" took care of him since he was three years old, he does not adopt her perception of religion and life by insisting that he is a "Muslim" like his "father". The viewpoint of the author can clearly be seen in the last sentence of the excerpt above that blames American women who marry "Muslim men" in particular.

Updike reveals that marriages to Arab and Muslim foreigners can also be problematic for the local wife herself. For instance, when Jack meets Ahmad's mother, she confesses to him that she has suffered greatly after she married the Egyptian: "We were a disaster ... He and I were crazy, thinking we ought to marry. We each thought the other had answers, when we didn't even speak the same language, literally. Though his English wasn't bad, to be fair..." (p.87). She considers her love to the Egyptian, Omar Ashmawy, as a mistake because they come from two different cultures, believe in two different religions, and speak different languages. Their differences become the primary cause of their estrangement. She is even alienated from her child, Ahmad, for her perception of "religion" is different from Ahmad's. She narrates: "Religion to me is a matter of attitude. It's saying yes to life. You have to have trust that there's a purpose, or you'll sink" (p.89). This portrayal and the previous characterisation of Ahmad uncover the author's point of view that rebuffs the Arab and Muslim migrants.

Metatextuality is not merely utilised by the author or narrator of the story; the characters themselves have their own voices which sometimes are at variance with the author's position. Yet, these character's voices are implicitly employed by the author to reinforce the theme of his novel. Within the narrative, the author has successfully created descriptions of scenes and dialogues between his imaginary characters to expose different opinions. For instance, the narrator in the excerpt below sheds light on Ahmad's oppositional views of the US culture:

Devils, Ahmad thinks. These devils seek to take away my God. All day long, at Central High School, girls sway and sneer and expose their soft bodies and alluring hair. Their bare bellies, adorned with shining navel studs and low-down purple tattoos, ask, what else is there to see? Boys strut and saunter along and look dead-eyed, indicating with their edgy killer gestures and careless scornful laughs that this world is all there is - a noisy varnished hall lined with metal lockers and having at its end a blank wall desecrated by graffiti and roller-painting over so often it feels to be coming closer by millimetres. The teachers, weak Christians and non-observant Jews, make a show of teaching virtue and righteous self-restraint, but their shifty eyes and hollow voices betray their lack of belief. They are paid to say these things, by the city of New Prospect and the state of New Jersey. They lack true faith; they are not on the Straight Path; they are unclean (p.1).

As seen above, Ahmad stands against the behaviour of his American classmates and he does not like his teachers. He views all of them as "devils". He feels alienated at his school because the students and teachers' values do not coincide with his Arabic and Islamic ones. He humiliates the "girls" who "sway and sneer and expose their soft bodies and alluring hair" and also those who "expose" "their bare bellies, adorned with shining navel studs and low-down purple tattoos". His question, "what else is there to see?" indicates that he does not agree with the perception of freedom that the US women believe in. This is because, as illustrated earlier, Ahmad belongs to his father's culture rather than his mother's. In addition to the female classmates, Ahmad condemns his male classmates who "strut and saunter along and look dead-eyed". He also hates "their edgy killer gestures and careless scornful laughs". Thus, he neither accepts the American girls, nor the boys.

Furthermore, Ahmad's rejection exceeds the students to the "teachers" for he considers them as "weak Christians and non-observant Jews" who "lack true faith". He even portrays them as "unclean". Ahmad uses this image to draw attention to their immoral deeds. He elsewhere claims that "some have the pink lids and bad breaths and puffy bodies of those who habitually drink too much. Some get divorces; some live with others unmarried. Their lives away from the school are disorderly and wanton and self-indulgent" (p.2). Due to 
their drinking and promiscuous ways, Ahmad declines them to be his teachers. In fact, such depictions indicate that Updike has wittily used Ahmad's refusal of the US girls, boys and teachers, to expose that Ahmad does not belong to the US culture. In other words, Ahmad's voice is employed by the narrator and author of the text against the transnational matrimonies because they result in children such as the Arab American, Ahmad, who is more an Arab and Muslim than an American.

Ahmad' repulse of the USA is not merely restricted to culture and identity, but it also includes the US history and policy. For instance, in his conversation with Jack below, Ahmad censures the US "colonialist" "history":

And because it has no God, it is obsessed with sex and luxury goods. Look at television, Mr. Levy, how it's always using sex to sell you things you don't need. Look at the history the school teaches, pure colonialist. Look how Christianity committed genocide on the Native Americans and undermined Asia and Africa and now is coming after Islam, with everything in Washington run by the Jews to keep themselves in Palestine (p.36).

Ahmad criticises the freedom that runs against human morality and utilises women as products for trading. He also reprimands the "genocide [of] the Native Americans" as well as the US support of Israel against the Palestinians. Besides, Ahmad in another dialogue tells his classmate, Joryleen, that the Americans are "slaves to drugs, slaves to fads, slaves to television, slaves to sports heroes that don't know they exist, slaves to the unholy, meaningless opinions of others" (p.71). In fact, Ahmad's stance of the USA has been constructed in this way because the imam, who teaches in a mosque where Ahmad attends, has an obvious influence on him. Among the imam's sayings about the USA, Ahmad reveals to Jack that the imam "said the college track exposed [Ahmad] to corrupting influences - bad philosophy and bad literature. Western culture is Godless" (p.35). From this, we can deduce that since Ahmad absorbs the ideas of the imam and glorifies them, he berates the US school, culture, history and policy.

Similarly, the narrator indirectly rejects bringing more Arabs and Muslims to the USA because he assumes that their national loyalty is not to the USA but to their motherlands. As a guidance counsellor at Central High School, Jack knows that Ahmad looks for a job. He suggests for Ahmad to join the army but Ahmad has another perspective. Ahmad declines to join the army in order not to be involved in the US occupation of Iraq:

"...If you have any Arabic they'd love you."

Ahmad's expression stiffens. "The Army would send me to fight my brothers."

"Or to fight for your brothers, it could be. Not all Iraqis are insurgents, you know. Most aren't. They just want to get on with business. Civilization started there. They had an up-and-coming little country, until Saddam."

The boy's eyebrows, thick and broad as a man's though the hairs are finger, knit into a scowl. Ahmad stands up to leave, but levy isn't quite ready to let him go. "I asked," he insists, "do you have any job lined up?"

The answer comes reluctantly: "My teacher thinks I should drive a truck" (p.38).

This conversation adds force to our earlier argument that Updike suspects the national loyalty of the Arab and Muslim Americans. As seen above, Ahmad upbraids the US occupation of Iraq, although he was born and bred in the USA. There is another significant precursor in the same dialogue. Ahmad distrusts his American school counsellor who provides him a job but at the same time accepts the job provided by the imam. He ends the conversation with this statement: "My teacher thinks that I should drive a truck." By the word "teacher", Ahmad means Shaikh Rashid who has been referred to in earlier discussions as the teacher or imam of the mosque.

Experiencing psychological indeterminate state, Ahmad lives in-between spaces. This can clearly be understood when he convincingly tells Joryleen that he is "a good Muslim, in a world that mocks faith" (p.67). He uses the word "world" to denote the USA where he lives. As a strict Muslim, Ahmad wants to live according to the regulations of Islam. However, he fails to do this in the USA. He reveals to his Arab American friend, Charlie, that: "I seek to walk the Straight Path ... In this country, it is not easy. There are too many paths, too much selling of many useless things. The brag of freedom, but freedom to no purpose becomes a kind of prison" (p.145). Ahmad's disagreement with the US "brag of freedom" alienates him. All these characteristics serve to show the worldviews of Arab Americans who cannot adapt with the ways of their adopted motherland. As a result, the author claims that their loyalty does not lie with the land which they have made their home.

The story even relates the failure of the US war on terrorism to some of those Arabs and Muslims who are Americans but loyal to their origins. For instance, the secretary of Homeland Security in the novel attempts to construe the factors hindering the US security agents from recognising the terrorists. He relates this failure to the some of his Arab and Muslim agents and "translators". He claims that the loyalty of those Muslim agents is not to the USA, but to their races or religions as can be seen in his conversation with Hermione below:

We know something about a truck, but don't know where it is or who's doing the driving. The explosives team, we got two out of the four, but they aren't talking, or else the translator isn't telling us what they're saying. They all cover for each other, even the ones on our payroll, you can't trust your own recruits any more (p.255).

The secretary above gets insufficient information about a terrorist explosion. Because of his fault for bad intelligence, he questions the loyalty of his agents. Although this quotation does not openly refer to the Arabs, the earlier discussions indicate that the secretary is actually referring to 
his agents of the Middle Eastern blood who, as he claims, "cover for each other". To reinforce this argument, we will refer to another excerpt in which Jack reveals at the end of the novel that "these Arabs all pressure each other with Islam" (Updike 2006: 287). These words provide evidence that the American officer has a deep distrust of his Arab agents. Although they are on American "payroll", their allegiance lies with their religion and original motherland. This insinuation is indeed biased and loaded with an anti-Arab ideology. It urges the US government to distrust all the Arabs even though they are Arab-Americans. This strengthens our earlier argument that Updike's text is extremely biased against the Arabs and Muslims.

The previous investigation, which relates the failure of the US war on terrorism to the disloyalty of the Arab agents and translators, is illogical. It indicates that "all" "Arabs" refuse to cooperate in the US war on terrorism as if the Arabs stand for terrorism. This manner of depicting the Arab Americans is an example of overgeneralisation or deformation of truth.

\section{Conclusion}

Our analysis of Updike's metatextuality of the transnational marriages has shown that Updike is extremely biased against the Arabs and Muslims. First, his refusal of these types of marriages concentrated merely on American women who marry Arab and Muslim migrants. Second, Updike develops dialogues to expose the Arab Americans as having strong Islamic identities which, as he claims, provoke them to reject the US liberal life and oppose the US policy and history. His novel reveals that these matrimonies result in confused American identities that live in-between spaces; they are neither Americans nor Arabs. Third, the novel questions the loyalty of those Arab Americans by claiming that their loyalties lie with the religion and culture of their Muslim fathers, not of the American mothers. This suspicion is intended to expose the Arab and Muslim Americans as dangerous for the US security. Hence, Updike's utilisation of each method to reject the Arab and Muslim Americans uncovers the author's anti-Arab and Muslim ideology.

\section{References}

[1] Ashipe, M. A. 2007. On being Updike forever: narcissism as national epic in John Updike's short fiction. Ph..D thesis. Washington University.
[2] Baldick, C. 1990. The concise Oxford dictionary of literary terms. Oxford: Oxford University Press.

[3] Chandler, D. 2007. Semiotics: the basics. London: Routledge.

[4] Deitering, C. 2008. Waste sites: rethinking nature, body, and home in American fiction since 1980. Ph.D thesis. Binghamton University: State University of New York.

[5] Genette, G. 1997[1982]. Palimpsest: literature in the second degree. Newman, C. \& Doubinsky. C. (trans.). New York: University of Nebraska Press.

[6] Holme, R. 2004. Literacy: an introduction. Edinburgh: Edinburgh University Press.

[7] Maira, S. 2009. Missing: youth, citizenship, and empire after 9/11. Duke University Press.

[8] Pape, D. J. 2008. Up out of this: metatextuality in Joyce's Ulysses. Master thesis. Villanova University.

[9] Popham, W. J. 2008. Transformative assessment. Alexandria: Association for Supervision and Curriculum Development.

[10] Riyad Manqoush, Noraini Md. Yusof, Ruzy Suliza Hashim. 2011. The use of historical allusion in recent American and Arab fiction. GEMA Online Journal of Language Studies 11(1): 57-68.

[11] Riyad Manqoush, Noraini Md. Yusof \& Ruzy Suliza Hashim. 2011. Depictions of Arabs in recent American fiction: a critical analysis of Adams' Harbor. In Raihanah M .M., Ruzy Suliza Hashim, Noraini Md. Yusof \& Zalina Lazim. (eds.). Gender, multiculturalism and re-visioning, pp. 43-58. Serdang: Universiti Putra Malaysia Press.

[12] Riyad Manqoush, Noraini Md. Yusof \& Ruzy Suliza Hashim. 2011. Modes of Intertextuality: Hypertextuality and Metatextuality of History in Early Twenty-First Century American and Arab fiction. Germany: Lambert for Academic Publishing.

[13] Riyad Manqoush, Noraini Md. Yusof \& Ruzy Suliza Hashim. 2011. Amplifications of religious fundamentalism in Fiction: al-Saqqaf's Qissat Irhabi vs. Updike's Terrorist. Middle East Studies Online Journal 3(6): 297-317.

[14] Stam, S. \& Raengo, A. 2005. Literature and film: a guide to the theory and practice of film adaptation. Oxford: Blackwell Publishing.

[15] Updike, J. 2006. Terrorist. New York: Ballantine Books. 